\title{
Results
}

1. The CHD group serum homacysteine level (24.36 $\pm 6.62 \mu \mathrm{mol} / \mathrm{l})$ was significantly higher than non-CHD group $(12.26 \pm 4.1 \mathrm{umol} / \mathrm{l})$. Serum homacysteine level were positively correlated with TCH $(p<0.01)$, negatively correlated with HDL $(p<0.01)$, FA $(p<0.01)$, Vit $B_{12}(p<0.05)$.

2. The level of serum homacystein in three subgroups was higher than non- CHD group, the integration of serum homacystein increased with the number of vascular lesions increased gradually, The difference was significant $(p<0.01)$.

3. high level of Serum homacysteine and $\mathrm{TCH}$, low level of Serum HDL, FA and Vit B12 were the risk factors of CHD using logstic regression analysis.

Conclusions The level of serum homacysteine can be used for indication of the degree of CHD in the clinical medicine.

\section{GW23-e1209 STUDY ON RELATIVITY BETWEEN SERUM HOMACYSTEINE LEVEL AND CORONARY ARTERY DISEASE SEVERITY}

doi:10.1136/heartjnl-2012-302920j.60

Wang Yue-Xi, Dong Li. Department of cardiology, First hospital affiliated to Inner Mogolian Medical University, Huhhot 010050, China

Objectives To discuss the relationship between Serum homacysteine (HCY) level and coronary artery lesion severity.

Methods 521 in hospital suspected cases with coronary heart disease (CHD) were collected from October 2008 to October 2010. 521 cases were divided into CHD group (384 cases) and non-CHD group (137 cases) diagnosed by angiography. Compare the difference of HCY, Acidum Folicum, Vit B12 among the two groups, and analysed the relationship between Serum homacysteine level and the degree of coronary artery disease. CHD group was divided to single, double and multi-vessel subgroups according to the severity of vascular lesions. Serum homacysteine levels were also compared among the three subgroups respectively. 